\title{
Early renal dysfunction after contrast media administration despite prophylactic hydration
}

\author{
Pawel Burchardt $\cdot$ Przemyslaw Guzik $\cdot$ Piotr Tabaczewski • \\ Tomasz Synowiec • Monika Bogdan • Paula Faner • \\ Anna Chmielarz-Sobocińska • Anna Palasz
}

Received: 14 September 2012/ Accepted: 23 January 2013/Published online: 3 February 2013

(c) The Author(s) 2013. This article is published with open access at Springerlink.com

\begin{abstract}
The actual incidence of renal dysfunction after contrast media administration seems to be underestimated, especially in the context of epidemiological data. There are only few data concerning the monitoring of impaired kidney function within a few hours after iodine contrast medium application. Hence, the purpose of this study is to observe the incidence of early renal function deterioration within $12-18 \mathrm{~h}$ after administration of iodine contrast media in patients scheduled for elective coronary angiography, who were intravenously and orally hydrated. In addition, the project aims to reclassify the contrast induced nephropathy phenomenon, by identification of early markers of renal dysfunction. Morphology, electrolytes, blood urea nitrogen (BUN), creatinine, low-density lipoprotein cholesterol, triglycerides, high-density lipoprotein, and total cholesterol levels were assessed with the use of typical laboratory techniques in 319 patients referred for coronary angiography. We demonstrated that early deterioration of renal function in patients 12-18 h after administration of contrast during imaging tests (even when appropriate prophylactic hydration
\end{abstract}

P. Burchardt $(\bowtie) \cdot$ P. Guzik · A. Palasz

Division of Cardiology-Intensive Therapy, Poznan University of Medical Sciences, ul. Przybyszewskiego 49, 60-355 Poznan, Poland

e-mail: pab2@tlen.pl

P. Tabaczewski

Department of Biology and Environmental Sciences, Poznan

University of Medical Sciences, Poznan, Poland

T. Synowiec

Department of General and Vascular Surgery and Angiology,

Poznan University of Medical Sciences, Poznan, Poland

M. Bogdan · P. Faner · A. Chmielarz-Sobocińska

Poznan University of Medical Sciences, Poznan, Poland was used), may occurred just as an increase (or no change) of serum creatinine level and BUN level and a decrease of creatinine clearance and glomerular filtration rate. Depending on the parameter, the phenomenon can be found in 13-28\% of all respondents. Early renal function impairment defined as above was almost 2 and $2.22 \times 10^{3}$ times (respectively) more frequently observed in our study than contrast induced nephropathy defined by current definitions.

Keywords Early contrast nephropathy - Coronary angiography · Acute kidney injury · Contrast-induced nephropathy $\cdot$ Serum creatinine

\section{Introduction}

Iodine contrast (JC) media may cause kidney insufficiency $[1,2]$. According to the increasing availability of imaging techniques with JC, renal disturbances recently become an important clinical problem. The phenomenon of contrast induced nephropathy (CIN) is currently defined as impairment of renal function which is manifested by an increase of creatinine of $0.5 \mathrm{mg} / \mathrm{dL}$ or $25 \%$ from baseline, or a decrease in creatinine clearance of more than $5 \mathrm{~mL} /$ $\mathrm{min}$ in the period from $24 \mathrm{~h}$ to 5 days after administration of contrast agent [3, 4]. Based on the above definition, it occurs in 1-6\% of population undergoing coronary angiography, of which about $0.3 \%$ require dialysis $[4,5]$. On the other hand, CIN was observed, even in up to $20 \%$ of patients with severe cardiovascular burden, undergoing imaging tests using JC $[5,6]$.

The early impairment of renal function within few hours after JC administration has not been clearly defined yet, nor has it been classified. Furthermore, the magnitude of this phenomenon is unknown. The actual incidence of 
renal dysfunction after JC administration seems to be underestimated, especially in the context of epidemiological data. Hence, the purpose of the project was to observe the incidence of early renal dysfunction within $12-18 \mathrm{~h}$ after administration of iodine contrast media in patients scheduled for elective coronary angiography, who were intravenously and orally hydrated. In addition, the project aims to reclassify the CIN phenomenon, by identifying early markers of renal dysfunction.

\section{Materials and methods}

This was a retrospective analysis performed in a single institution in 2010 and 2011. The enrollment period was 16 months. Four hundred and forty two patients were recruited to the study, but due to data deficiency, hydration protocol deviations and exclusion criteria only 319 subjects were joined. From each patient blood samples for laboratory tests were taken twice. For the first time upon on admission to the hospital. A second blood sampling was performed after complete saline administration and within $12-18 \mathrm{~h}$ after completion of coronary angiography or percutaneous coronary angioplasty. Patients were periprocedurally (during $24 \mathrm{~h}$ ) irrigated intravenously (at least $5 \mathrm{~h}$ before and up to $10 \mathrm{~h}$ after angiography) with commercially available saline enriched with $0.038 \mathrm{~g} / 100 \mathrm{~mL}$ of KCL, $0.0394 \mathrm{~g} / 100 \mathrm{~mL}$ of $\left(\mathrm{CaCl}_{2} \cdot 6 \mathrm{H}_{2} \mathrm{O}\right), 0.02 \mathrm{~g} / 100 \mathrm{~mL},\left(\mathrm{MgCl}_{2} \cdot 6 \mathrm{H}_{2} \mathrm{O}\right), 0.462 \mathrm{~g} /$ $100 \mathrm{~mL}\left(\mathrm{CH}_{3} \mathrm{COONa} \cdot 3 \mathrm{H}_{2} \mathrm{O}\right), 0.09 \mathrm{~g} / 100 \mathrm{~mL}(\mathrm{C} 6 \mathrm{H} 5 \mathrm{Na} 3 \mathrm{O} 7$. 2H2O) (Fresenius Kabi, Poland). The osmolality of media was $301 \mathrm{~m} \mathrm{OSM} / \mathrm{L}$, The total amount of intravenous liquids were administered according to European Society of Cardiology (ESC) guidelines [7] but were individually modified by physicians (patients with serum creatinine levels above the laboratory norm at admission, received higher volume of saline). Subjects with heart failure were also irrigated according to ESC guidelines [7] and had controlled diuresis. Additionally, our in-ward protocol included $24 \mathrm{~h}$ periprocedural (at least $5 \mathrm{~h}$ before and up to $10 \mathrm{~h}$ after angiography) oral hydration in the amount of $1,500 \mathrm{~mL}$ of water for every studied patient. The protocol of irrigation was considered for all patients and only subjects who met these requirements were retrospectively qualified for the study.

Diabetes and hypertension were established according to ESC guidelines [8] or according to previous hospital discharge cards.

Deterioration of renal function was defined

- as an increase (or no change) of serum creatinine

- decrease (or no change) in creatinine clearance rate (CCR) and glomerular filtration rate (GFR)/expressed by different formulas/.
- decrease creatinine clearance and GFR by more than $5 \mathrm{~mL} / \mathrm{min}$ and $\mathrm{mL} / \mathrm{min} / 1.73 \mathrm{~m}^{2}$ respectively.

- decrease in creatinine clearance and GFR by more than $5 \%$.

Evaluation of creatinine clearance by Cocroft-Gault $[9,10]$ and GFR by CKD EPI (Chronic Kidney Disease Epidemiology Collaboration) [11] and MDRD (Modification of Diet in Renal Disease) [12] was based on a formula available online (http://en.wikipedia.org/wiki/Renal_ function).

\section{Inclusion criteria}

Study included 319 patients undergoing routine coronary angiography due to the clinical symptoms of ischemic heart disease.

\section{Exclusion criteria}

Patients with acute coronary syndrome and subjects who had acute coronary syndrome less than 5 weeks earlier were excluded. We additionally excluded patients with heart failure in NYHA IV and or ejection fraction below $30 \%$ (this information was collected from medical records and clinical examination).

The study used two types of angiographic isoosmolar contrast agents: IOMERON 350 (Bracco Imaging, Germany), OPTIRAY 350 (Tyco Healthcare, Germany).

The maximum contrast dose was calculated according to proposed [13] formula: (5 times the weight of the patient/ baseline serum creatinine level). The contrast index' (amount of contrast used, to a maximum dose of contrast) as well as ratio of used contrast per creatinine clearance [14] were assessed.

\section{Laboratory parameters}

Creatinine levels, were assessed by using buffered kinetic Jaffe reaction without deproteinisation kit-C system Cobas 6000 (Roche Diagnostics, Germany). Method was calibrated by isotope dilution mass spectrometry). Blood urea nitrogen (BUN), uric acid, triglicerydes (TG), cholesterol, high density lipoproteins were quantitatively determined by enzymatic colorimetric method using Cobas 6000 (Roche Diagnostics, Germany) system with sophisticated reagents. Low density lipoproteins (LDL) were measured by indirected way with Freidewald formula. TSH was measured by electrochemiluminescent method with using the Cobas 6000 (Roche Diagnostics, Germany) analyzer with Roche reagents Germany. Electrolytes, were measured by ion selective, potentiometric method using Cobas 
6000 (Roche Diagnostics, Germany). Morphology was assessed using Sysmex XT2000i (Sysmex, USA).

\section{Statistics}

Normality was tested in the Shapiro-Wilk's W test. At normal distribution of variables the T-Student test for two independent and dependent variables was used. MannWhitney test for two independent variables and Sign test as well as Wilcoxon matched pairs test for two dependent variables were used at abnormal variables distribution. The binomial test were used for comparing standard and 'non standard' definition of CIN.

The results are given as mean $\pm \mathrm{SD}$. The statistical significance was established when $p<0.05$. Statistical analysis was conducted using STATISTICA 8.0 software.

\section{Results}

The study was conducted in 319 patients undergoing elective coronary angiography at the age of 60.62 years \pm 8.63 . The mean body mass index (BMI) in the study population was $29.09 \pm 4.97 \mathrm{~kg} / \mathrm{m}^{2}$. Fifty nine percent of patients were male, $41 \%$ women. Hypertension, impaired glucose metabolism (glucose intolerance, impaired fasting glucose and diabetes mellitus combined), previous myocardial infarction, previous renal insufficiency (GFR/by $\mathrm{MDRD} /<60 \mathrm{~mL} / \mathrm{min} / 1.73 \mathrm{~m}^{2}$ ) and heart failure (up to NYHA III) subsequently were reported in 85, 44.5, 37.3, 14.7 and $19.1 \%$, respectively. Fifty six percent of patients who underwent elective coronarography, had percutaneous transluminal coronary angioplasty (PTCA) undertaken within the same procedure. The evaluation of examined laboratory parameters are shown in Table 1. Patients received an average of $112.46 \pm 57.85 \mathrm{~mL}$ of contrast (coro + PTCA) and $0.54 \pm 0.54 \mathrm{~Gy}$ of radiation (coro + PTCA). The procedure lasted a total of $26.19 \pm 20.86$ (coro + PTCA) minutes, and total fluoroscopy time was $5.5 \pm 7.47 \mathrm{~min}$ (coro + PTCA). Patients were periprocedurally hydrated intravenously with commercially available $\mathrm{K}^{+}, \mathrm{MG}^{2+}$ and $\mathrm{Ca}^{2+}$ enriched saline solution in an amount of $1,614.42 \pm 221.3 \mathrm{~mL}$ and $1,500 \mathrm{~mL}$ of fluid po (per os). The maximum contrast dose (5 times the weight of the patient/baseline serum creatinine level) was $514.58 \pm 155.46 \mathrm{~mL}$. 'The contrast index' (amount of contrast used, to a maximum dose of contrast) was $0.24 \pm 0.17$. Ratio of used contrast per creatinine clearance [10] was equal to $1.29 \pm 1.02$. Seventy nine point one percent of patients were taking angiotensin converting enzyme-inhibitors (ACE-i), $9.7 \%$ of patients were taking angiotensin receptor blockers (ARB), 85.9\% of patients were taking beta blockers $(\mathrm{BB})$, diuretics and statins were taken respectively by 39.22 and $95.01 \%$ of studied subjects. Study groups (with or without renal deterioration) did not differ in scope of pharmacotherapy profiles.

Assessment of renal function after $12-18 \mathrm{~h}$ after administration of $\mathrm{JC}$, and hydration compared to measurements on admission to the hospital

Statistically significant decrease in creatinine $(0.93 \pm 0.46$ vs. $0.87 \pm 0.47 \mathrm{mg} / \mathrm{dL}, p<0.001)$ and BUN $(37 \pm 12.4$ vs. $29.64 \pm 10.67 \mathrm{mg} / \mathrm{dL}, p<0.001)$, higher creatinine clearance $(100.33 \pm 36.2$ vs. $107,67 \pm 38.5 \mathrm{~mL} / \mathrm{min}$, $p<0.001)$ and glomerular filtration rate according to the MDRD formula $(81.6 \pm 23.03$ vs. $88,75 \pm 25.39 \mathrm{~mL} /$ $\left.\min / 1.73 \mathrm{~m}^{2}, p<0.001\right)$ or CKD EPI (83.1 \pm 19.7 vs. $\left.87.2 \pm 18.8 \mathrm{~mL} / \mathrm{min} / 1.73 \mathrm{~m}^{2} p<0.001\right)$ were noticed in control parameters assessment in whole group (after the JC and the use of prophylactic hydration). In addition, we observed statistically significant decrease in the number of red blood cells $\left(\times 10^{6} / \mu \mathrm{L}\right)(4.56 \pm 0.47$ vs. $4.3 \pm 0.51$, $p<0.001$, hemoglobin (HGB) (g/dL) $(13.9 \pm 1.4$ vs. $13.0 \pm 1.53, p<0.001)$, hematocrit (HCT) $(\%)(40.5 \pm 3.7$ vs. $38.4 \pm 4.3, p<0.001)$.

Markers of impaired renal function

A. Decrease (or no change) in creatinine clearance, decrease in creatinine clearance by more than $5 \mathrm{~mL} /$ min and decrease in creatinine clearance by more than $5 \%$ were found in $23.8,14.4$, and $13.7 \%$ of respondents respectively (Fig. 1).

B. Reduction (or no change) of CKD according to EPI, reduction of $\mathrm{CKD}$ according to $\mathrm{EPI}$ by more than $5 \mathrm{~mL} / \mathrm{min} / 1.73 \mathrm{~m}^{2}$ and a decrease of CKD according to EPI by more than $5 \%$ were found in $28.5,11.2$, and $11.9 \%$, respectively.

C. Reduction (or no change) of MDRD, MDRD decrease by more than $5 \mathrm{~mL} / \mathrm{min} / 1.73 \mathrm{~m}^{2}$ and a decrease in MDRD by more than $5 \%$ was found in $23.8,14.7$ and $15.9 \%$ of respondents respectively.

D. After $12-18 \mathrm{~h}$ of contrast administration, an increase or no change in the serum creatinine and BUN levels (despite of hydration) were observed in 27.6 and $12.8 \%$ of respondents respectively, an increase in creatinine of $>25 \%$ occurred in $0.09 \%$ of all patients.

Individuals with (no change or) reduction in creatinine clearance or glomerular filtration rate (established according to CKD EPI or MDRD), with decrease of these parameters for $5 \mathrm{~mL} / \mathrm{min} / 1.73 \mathrm{~m}^{2}$ and their decline by more than $5 \%$, significantly differed from the rest of the patients by: age, the amount of contrast media used and 
Table 1 Characteristics of studied group

\begin{tabular}{|c|c|}
\hline & $\begin{array}{l}\text { Studied group } \\
\text { Mean } \pm \mathrm{SD} \\
(\mathrm{N}=319)\end{array}$ \\
\hline Age (years) & $60.6 \pm 8.6$ \\
\hline $\operatorname{BMI}\left(\mathrm{kg} / \mathrm{m}^{2}\right)$ & $29.1 \pm 4.97$ \\
\hline Hypertension $(\%)$ & 85 \\
\hline $\begin{array}{l}\text { Glucose metabolism disturbances } \\
\text { (IFG, IGT, DM) (\%) }\end{array}$ & 44.5 \\
\hline Heart failure $(\%)$ & 19.1 \\
\hline Previous myocardial infarction $(\%)$ & 37.1 \\
\hline Previous PTCA $(\%)$ & 36.04 \\
\hline Previous CABG (\%) & 3.1 \\
\hline Dyslipidemia & 38.1 \\
\hline $\begin{array}{l}\text { Chronic kidney disease }(\%)(\mathrm{GFR}<60 \\
\left(\mathrm{mL} / \mathrm{min} / 1.73 \mathrm{~m}^{2}\right)\end{array}$ & 14.7 \\
\hline Creatinine baseline (mg/dL) & $0.93 \pm 0.46$ \\
\hline $\begin{array}{l}\text { Creatinine after } 12-18 \mathrm{~h} \text { from JC administration } \\
(\mathrm{mg} / \mathrm{dL})\end{array}$ & $0.87 \pm 0.47$ \\
\hline RBC baseline $\left(\times 10^{6} / \mu \mathrm{L}\right)$ & $4.57 \pm 0.47$ \\
\hline $\begin{array}{l}\text { RBC after } 12-18 \mathrm{~h} \text { from JC administration } \\
\left(\times 10^{6} / \mu \mathrm{L}\right)\end{array}$ & $4.3 \pm 0.5$ \\
\hline HGB baseline (g/dL) & $13.9 \pm 1.4$ \\
\hline HGB after $12-18 \mathrm{~h}$ from JC administration $(\mathrm{g} / \mathrm{dL})$ & $13.04 \pm 1.54$ \\
\hline HCT baseline $(\%)$ & $40.55 \pm 3.71$ \\
\hline HCT after $12-18 \mathrm{~h}$ from JC administration (\%) & $38.4 \pm 4.31$ \\
\hline BUN baseline (mg/dL) & $37.0 \pm 12.44$ \\
\hline BUN after $12-18 \mathrm{~h}$ from $\mathrm{JC}$ administration $(\mathrm{mg} / \mathrm{dL})$ & $29.65 \pm 10.67$ \\
\hline Uric acid (mg/dL) & $5.67 \pm 1.63$ \\
\hline $\mathrm{TSH}(\mu \mathrm{U} / \mathrm{mL})$ & $1.8 \pm 1.43$ \\
\hline $\mathrm{TC}(\mathrm{mg} / \mathrm{dL})$ & $178.94 \pm 68.4$ \\
\hline
\end{tabular}

$B U N$ blood urea nitrogen, $C A B G$ coronary artery by-pass graft, $G F R$ glomerular filtration rate, $H C T$ hematocrit, $H G B$ hemoglobin, $J C$ iodine contrast, $L D L$ low density lipoprotein, PTCA percutaneous transluminal coronary angioplasty, $R B C$ red blood cells, $T C$ total cholesterol, TSH thyroid stimulating hormone

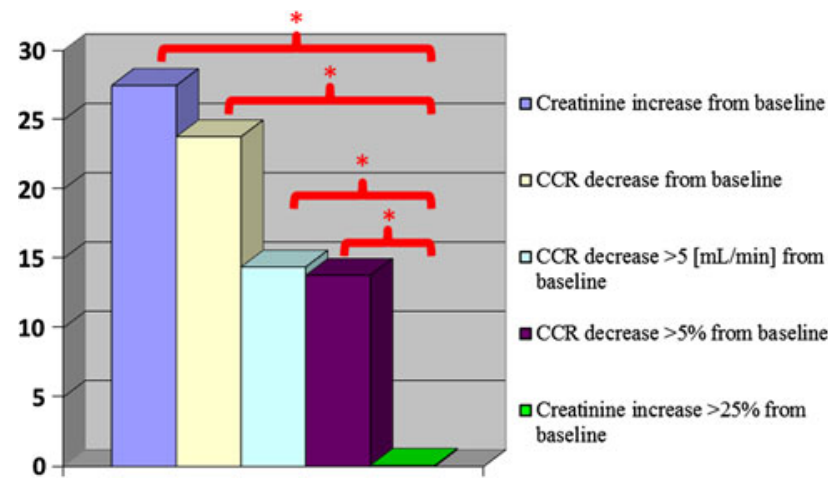

Fig. 1 Comparison of various CIN criteria in studied population. Legend: $* p<0.05$ presences of combined glucose metabolism disturbances (IFG, IGT, DM) (Table 2). In male versus female group there were significantly higher rate of (no change or) reduction in $\mathrm{CCR}(17.24$ vs. $6.9 \%, p=0,01)$ or GFR (CKD EPI 22 vs. $6.9 \%, p<0.001$ or MDRD 16.9 vs. $6.9 \%, p=0,014)$. Although, statistically insignificant trend in male group was observed where patients show a decrease of these parameters for $5 \mathrm{~mL} / \mathrm{min} / 1.73 \mathrm{~m}^{2}$ and their decline by more than $5 \%$. Men had also significantly more often increased creatinine after angiography (19 vs. $9 \% p=0.04)$. The percent number of patients who suffered from heart failure or chronic kidney disease at the beginning of the study were comparable between patients with or without impaired renal function after contrast media administration.

Differences between the standard definition of CIN and the proposed new definition

Standard definitions of contrast induced nephropathy were considered: (A) when GFR or CCR decreased by $5 \mathrm{~mL} /$ $\mathrm{min} / 1.73 \mathrm{~m}^{2}$ or $5 \mathrm{~mL} / \mathrm{min}$, (B) creatinine level increases by $25 \%$ or $0.5 \mathrm{mg} / \mathrm{dL}$. The significant differences were found between the standard definition A and CIN interpreted as a decline in (GFR), $p<0.001$ (by CKD EPI), and $p<0.001$ (by MDRD) or creatinine clearance $p=0.0026$.

We found statistically significant differences between the standard definition B, and CIN interpreted as an increase (or no change) in serum creatinine level, $p<0.001$. Renal function impairment defined as a decrease (or no change) in GFR, CCR or increase (and no change) in serum creatinine level was almost 2 and $2.22 \times 10^{3}$ times (respectively) more frequently observed than nephropathy defined as A or B.

The association between disparity of creatinine clearance (calculated according to Cocroft-Gault formula) and serum creatinine level

The association between disparity of creatinine clearance and disparity of pure creatinine serum levels is non linear and is shown at Fig. 2. The simulation was performed for a woman, $175 \mathrm{~cm}, 80 \mathrm{~kg}, 50$ years, with different baseline serum creatinine levels (from 0.5 to $2.5 \mathrm{mg} / \mathrm{dL}$ ).

\section{Discussion}

Contrast induced nephropathy has ischemic etiology. JC probably causes reduction of oxygen tension in both medulla and cortex thus increasing the oxygen tension imbalance between these two compartments. Ischemia is 
Table 2 Parameters which significantly differ the groups of patients with various definition of post-contrast renal deterioration phenomenon (the asterisk shown on the second row mean that all comparisons within the 3 groups are statistically significant)

\begin{tabular}{|c|c|c|c|c|c|c|}
\hline & \multicolumn{2}{|c|}{ CCR decrease $>5(\mathrm{~mL} / \mathrm{min})$} & \multicolumn{2}{|c|}{ CCR decrease $>5 \%$} & \multicolumn{2}{|l|}{ CCR decrease } \\
\hline & $\mathrm{YES} / \mathrm{N}=46$ & $\begin{array}{l}\mathrm{NO} * / \\
\mathrm{N}=273\end{array}$ & $\mathrm{YES} / \mathrm{N}=44$ & $\begin{array}{l}\mathrm{NO} * * / \\
\mathrm{N}=275\end{array}$ & $\mathrm{YES} / \mathrm{N}=76$ & $\begin{array}{l}\mathrm{NO} * * * / \\
\mathrm{N}=243\end{array}$ \\
\hline Age (years) & $57.5 \pm 8.6$ & $61.1 \pm 8.5$ & & & $58.47 \pm 8.5$ & $61.1 \pm 8.5$ \\
\hline Creatinine (baseline) $(\mathrm{mg} / \mathrm{dL})$ & $0.8 \pm 0.2$ & $0.95 \pm 0.5$ & $0.93 \pm 0.8$ & $0.93 \pm 0.38$ & $0.9 \pm 0.6$ & $0.96 \pm 0.5$ \\
\hline $\begin{array}{l}\text { Creatinine (after } 12-18 \mathrm{~h} \text { from JC } \\
\text { administration) }(\mathrm{mg} / \mathrm{dL})\end{array}$ & $0.9 \pm 0.2$ & $0.86 \pm 0.5$ & $1.05 \pm 0.9$ & $0.84 \pm 0.33$ & $0.96 \pm 0.7$ & $0.86 \pm 0.5$ \\
\hline $\begin{array}{l}\mathrm{CR} \text { (after } 12-18 \mathrm{~h} \text { from JC administration) } \\
\text { minus } \mathrm{CR} \text { (baseline) }(\mathrm{mg} / \mathrm{dL})\end{array}$ & $0.3 \pm 1.4$ & $-0.09 \pm 0.1$ & $0.3 \pm 1.4$ & $-0.09 \pm 0.1$ & $0.2 \pm 1.1$ & $-0.1 \pm 0.1$ \\
\hline $\begin{array}{l}\text { Ratio of CR (after } 12-18 \mathrm{~h} \text { from JC } \\
\text { administration)/CR (baseline) }\end{array}$ & $1.1 \pm 0.06$ & $0.9 \pm 0.08$ & $1.1 \pm 0.06$ & $0.9 \pm 0.08$ & $1.08 \pm 0.07$ & $0.9 \pm 0.08$ \\
\hline $\mathrm{RBC}$ (baseline) $\left(\times 10^{6} / \mu \mathrm{L}\right)$ & $4.7 \pm 0.5$ & $4.5 \pm 0.5$ & $4.7 \pm 0.5$ & $4.5 \pm 0.5$ & $4.7 \pm 0.5$ & $4.5 \pm 0.5$ \\
\hline $\begin{array}{l}\text { RBC (after } 12-18 \mathrm{~h} \text { from JC administration) } \\
\left(\times 10^{6} / \mu \mathrm{L}\right)\end{array}$ & $4.5 \pm 0.6$ & $4.3 \pm 0.5$ & $4.5 \pm 0.6$ & $4.3 \pm 0.5$ & $4.5 \pm 0.55$ & $4.3 \pm 0.5$ \\
\hline HGB (baseline) (g/dL) & $14.5 \pm 1.2$ & $13.8 \pm 1.4$ & $14.4 \pm 1.3$ & $13.8 \pm 1.4$ & $14.4 \pm 1.3$ & $13.8 \pm 1.4$ \\
\hline $\begin{array}{l}\text { HGB (after } 12-18 \text { h from JC administration) } \\
(\mathrm{g} / \mathrm{dL})\end{array}$ & $13.7 \pm 1.4$ & $12.9 \pm 1.5$ & $13.65 \pm 1.4$ & $12.9 \pm 1.5$ & $13.6 \pm 1.5$ & $12.9 \pm 1.5$ \\
\hline $\begin{array}{l}\text { Ratio of HGB (after } 12-18 \mathrm{~h} \text { from JC } \\
\text { administration)/HGB (baseline) }\end{array}$ & & & & & $0.95 \pm 0.05$ & $0.9 \pm 0.06$ \\
\hline HCT (baseline) (\%) & $41.9 \pm 3.5$ & $40.3 \pm 3.7$ & $41.7 \pm 3.5$ & $40.4 \pm 3.7$ & $41.65 \pm 3.6$ & $40.3 \pm 3.7$ \\
\hline $\begin{array}{l}\text { HCT (after } 12-18 \mathrm{~h} \text { from JC administration) } \\
(\%)\end{array}$ & $40.2 \pm 4$ & $38.1 \pm 4.3$ & $40.1 \pm 4$ & $38.1 \pm 4.3$ & $40.2 \pm 4.2$ & $38.1 \pm 4.3$ \\
\hline $\begin{array}{l}\text { HCT (after } 12-18 \mathrm{~h} \text { from JC administration) } \\
\text { minus HCT (baseline) }(\%)\end{array}$ & & & $-1.5 \pm 2.3$ & $-2.24 \pm 2.6$ & $-1.5 \pm 2.45$ & $-2.2 \pm 2.6$ \\
\hline $\begin{array}{l}\text { Ratio of HCT (after } 12-18 \mathrm{~h} \text { from JC } \\
\text { administration)/HCT (baseline) }\end{array}$ & & & $1 \pm 0.05$ & $0.9 \pm 0.06$ & $1 \pm 0.06$ & $0.9 \pm 0.06$ \\
\hline BUN (baseline) (mg/dL) & & & & & $33.9 \pm 9.4$ & $37.6 \pm 13$ \\
\hline $\begin{array}{l}\text { BUN (after } 12-18 \mathrm{~h} \text { from JC administration) } \\
\text { minus BUN (baseline) }(\mathrm{mg} / \mathrm{dL})\end{array}$ & $-4.52 \pm 6$ & $-7.8 \pm 6.7$ & $-3.77 \pm 5.9$ & $-7.9 \pm 6.7$ & $-4.3 \pm 6.6$ & $-7.8 \pm 6.7$ \\
\hline $\begin{array}{l}\text { Ratio of BUN (after } 12-18 \mathrm{~h} \text { from JC } \\
\text { administration)/BUN (baseline) }\end{array}$ & $0.88 \pm 0.2$ & $0.8 \pm 0.15$ & $0.9 \pm 0.17$ & $0.8 \pm 0.15$ & $0.88 \pm 0.2$ & $0.8 \pm 0.15$ \\
\hline $\mathrm{TC}(\mathrm{mg} / \mathrm{dL})$ & $211.5 \pm 146$ & $173.5 \pm 41.5$ & & & & \\
\hline $\mathrm{LDL}(\mathrm{mg} / \mathrm{dL})$ & $114.7 \pm 48.4$ & $96.8 \pm 32.3$ & & & & \\
\hline Ratio of Contrast volume/SCR (baseline) & $1.02 \pm 0.7$ & $1.3 \pm 1.05$ & & & $1.0 \pm 0.64$ & $1.4 \pm 1.08$ \\
\hline
\end{tabular}

$B U N$ blood urea nitrogen, $C R$ serum creatinine, $C C R$ creatinine clearance, $H C T$ hematocrit, $H G B$ hemoglobin, $J C$ iodine contrast, $L D L$ low density lipoprotein, $R B C$ red blood cells, $T C$ total cholesterol

$* p<0.05$ between patients with CCR decrease $>5(\mathrm{~mL} / \mathrm{min})$ and without

$* * p<0.05$ between patients with CCR decrease $>5 \%$ and without

*** $p<0.05$ between patients with no change or CCR decrease versus CCR increase

intensified by an increased release of endothelin and adenosine $[15,16]$ and may be enhanced by the production of reactive oxygen species [3]. One can not exclude a direct toxic effect of contrast on renal tubular epithelium as well [17-19]. Despite many attempts to prevent CIN, the best results were obtained with hydration of the patients during the periprocedure period $[3,7]$.

In clinical practice, the phenomenon of contrast nephropathy is described as impaired renal function from $24 \mathrm{~h}$ to 5 days after administration of contrast agent. However, in defining CIN phenomenon, still large discrepancies exist. These relate to the time after administration of contrast, the impairment of renal function, the choice of parameters used to describe renal function and extent of their changes.

In our study we noticed improvement of the baseline renal function after 12-18 $\mathrm{h}$ from contrast use and after the hydration of the patients $(3,150 \mathrm{~mL}$ during the period immediately before and after the procedure $/ 1,500 \mathrm{~mL}$ orally + intravenously $1,614.42 \pm 221.3 \mathrm{~mL} /$ ). However, in absolute levels the creatinine increased (or no changed) in $28 \%$ of subjects. Twenty eight point seven percent and 
Fig. 2 Non-linear association between SCR and CCR according to various baseline creatinine levels

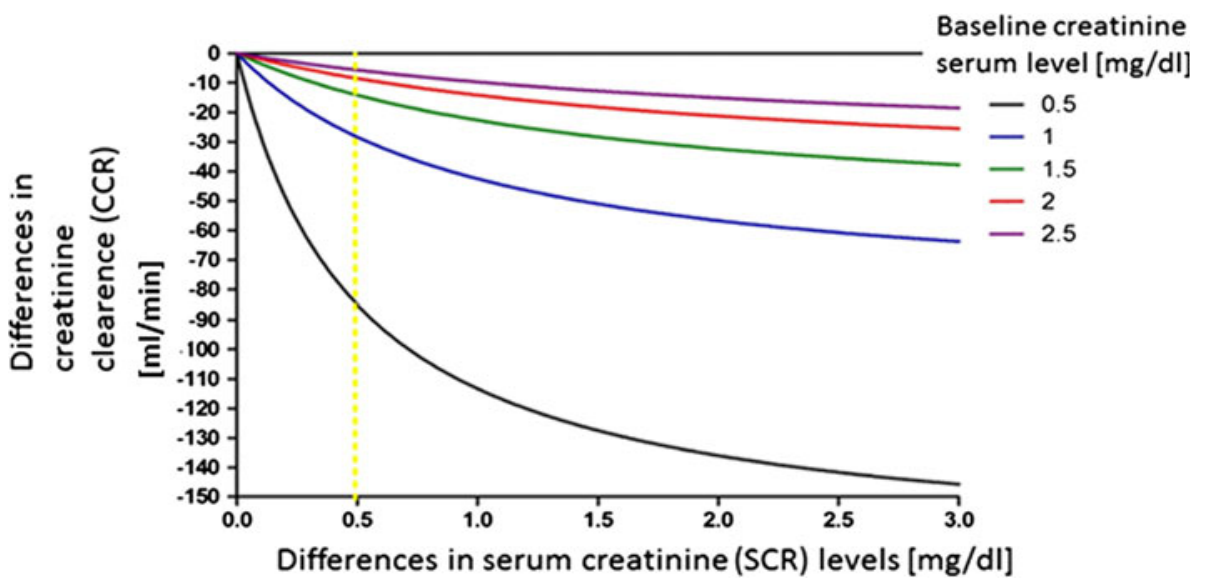

$27.7 \%$ of patients subsequently decline in creatinine clearance, or (variously defined), glomerular filtration rate. It should be noted, that individuals in whom we have noticed this phenomenon were older and had significantly higher baseline and control levels of: BUN, creatinine, HGB, RBC and HCT. Additionally those patients more often than others experienced combined glucose metabolism disturbances. Surprisingly, the percent number of patients who suffered from heart failure or chronic kidney disease at the beginning of the study was not significant and didn't differ between patients with or without impaired renal function after contrast media administration. It is probably due to the fact that we included only those subjects who displayed up to moderate heart failure. However, we observed nonsignificant statistical trend toward more frequent number of subjects with the baseline chronic kidney disease, which is consistent with the literature [4-6, 14]. The renal dysfunction was more often observed in male group. Only possible explanation for this is the fact, that male group was more frequently (although statistically insignificant) affected by heart failure and chronic kidney disease before study, what may have interfered with their renal pattern, during our analysis.

The decrease in creatinine clearance of $5 \mathrm{~mL} / \mathrm{min}$, was the most radical definition of CIN we have found in the literature [3, 4], and it was observed in approximately $14 \%$ of all analyzed subjects. In our study any impairment of renal function according to our criteria was noticed twice as often as when defined by standard definition. On the other hand, when we considered the CIN creatinine increase of $25 \%$ or about $0.5 \mathrm{mg}$ of the output $[3,4]$, the phenomenon has occurred in only $0.9 \%$ of the studied population. Although the deterioration in renal function manifested by an increase (or no change) of creatinine was up to $2.22 \times 10^{3}$ times more frequently observed then current CIN definition.

The use of different parameters to the interpretation of CIN is not random in our study. Serum creatinine levels is not a equivalent of creatinine clearance, which is in clinical conditions mostly calculated according to Cocroft-Gault formula. This is confirmed by the simulation performed for a woman, $175 \mathrm{~cm}, 80 \mathrm{~kg}, 50$ years, with different baseline serum creatinine levels (from 0.5 to $2.5 \mathrm{mg} / \mathrm{dL}$ ). We showed, that the association between disparity of creatinine clearance (between measurements at the beginning and at the end point) and disparity of pure creatinine serum levels (between measurements at the beginning and at the end point) is non-linear, and depends on the creatinine baseline (Fig. 2). Thus, the higher the level, at the baseline the decline in creatinine clearance is greater.

These data (as well as 3 other [20-22]) therefore seem to confirm the need to revise the criteria for the diagnosis of CIN, particularly on the basis of early (within several hours) [22] measurements of creatinine, creatinine clearance and glomerular filtration rate. This is an extremely significant clinical problem, especially in the context of discharging the patients (undergoing routine coronary angiography) from hospital on the next day after the procedure. This is also important due to the fact that CIN worsens the prognosis of patients, being an independent risk factor for future chronic kidney disease. The proposed interpretation of contrast nephropathy phenomenon based on the early decline in renal function after administration of JC, therefore allows to separate high risk groups as well as to have time to implement appropriate clinical management. We propose in such cases to extend the hospitalization time until the return of serum creatinine to the baseline levels. Additional saline and acetylcysteine irrigation is then to be individually considered and the creatinine and BUN levels are to be strictly controlled. After discharge every patient is to be obligatory scheduled for ambulatory nephrological inspection.

Limitation of the study is the fact that this is a retrospective, observational analysis. Hence, there was no single control time measurement of the analyzed parameters. Patients were irrigated periprocedurally according to ESC 
guidelines and it took $24 \mathrm{~h}$. However, according to ward protocol we used to start irrigation at least $5 \mathrm{~h}$ before procedure, and in other cases (when time of starting the angiography was late) we continued it up to $10 \mathrm{~h}$ after the procedure. It means that patients who received the same volume of hydration may differ each other in volume of irrigated liquids provided (in period) before as well as after the procedure, what depends on the time of starting the procedure. Furthermore, the patients' weight on the next day after irrigation is unknown. In addition, we do not know the levels of BUN and creatinine, in the period from 3 to 7 days after administration of contrast medium. Creatinine assessment method error is $\pm 8 \%$, but every indication was performed under identical conditions, so the 'constant error' was eliminated. Another limitation of this study was that two similar but not identical contrast media of similar osmolality and iodine content were used. The undeniable strengths of our analysis include the fact of homogeneity of the study population according to pharmacotherapy, and homogeneity of hydration procedures.

Giving the implications of this study, perhaps larger prospective study should be considered in the future.

\section{Conclusions}

Impairment of renal function 12-18 h after contrast agent administration (even when prophylactic hydration is used), may result in no change or an increase of creatinine and BUN and a decrease (or no change) in CCR and GFR. Depending on the parameter, the phenomenon was detected in 13 to $28 \%$ of our patients. The early renal dysfunction identified as above is twice more frequent than the most stringent current definition of CIN. The results need confirmation in a large clinical group.

\section{Conflict of interest None.}

Open Access This article is distributed under the terms of the Creative Commons Attribution License which permits any use, distribution, and reproduction in any medium, provided the original author(s) and the source are credited.

\section{References}

1. Dangas G, Iakovou I, Nikolsky E, Aymong ED, Mintz GS, Kipshidze NN, Lansky AJ, Moussa I, Stone GW, Moses JW, Leon MB, Mehran R (2005) Contrast-induced nephropathy after percutaneous coronary interventions in relation to chronic kidney disease and hemodynamic variables. Am J Cardiol 95(1):13-19

2. Marenzi G, Lauri G, Assanelli E, Campodonico J, De Metrio M, Marana I, Grazi M, Veglia F, Bartorelli AL (2004) Contrastinduced nephropathy in patients undergoing primary angioplasty for acute myocardial infarction. J Am Coll Cardiol 44(9): $1780-1785$

3. Schweiger MJ, Chambers CE, Davidson CJ, Blankenship J, Bhalla NP, Block PC, Dervan JP, Gasperetti C, Gerber L, Kleiman NS, Krone RJ, Phillips WJ, Siegel RM, Uretsky BF, Laskey WK (2007) Prevention of contrast induced nephropathy: recommendations for the high risk patient undergoing cardiovascular procedures. Catheter Cardiovasc Interv 69:135-140

4. Shoukat S, Gowani SA, Jafferani A, Dhakam SH (2010) Contrast-induced nephropathy in patients undergoing percutaneous coronary intervention. Cardiol Res Pract 1:12. doi:10.4061/ 2010/649164

5. Parfrey P (2005) The clinical epidemiology of contrast-induced nephropathy. Cardiovasc Intervent Radiol 28(suppl 2):s3-s11

6. Rihal CS, Textor SC, Grill DE, Berger PB, Ting HH, Best PJ, Singh M, Bell MR, Barsness GW, Mathew V, Garratt KN, Holmes DR Jr (2002) Incidence and prognostic importance of acute renal failure after percutaneous coronary intervention. Circulation 105(19):2259-2264

7. Wijns W, Kolh P, Danchin N et al (2010) Guidelines on myocardial revascularization: the task force on myocardial revascularization of the European Society of Cardiology (ESC) and the European Association for Cardio-Thoracic Surgery (EACTS). Eur Heart J 31:2501-2555

8. Rydén L, Standl E, Bartnik M et al (2007) Guidelines on diabetes, pre-diabetes, and cardiovascular diseases: executive summary. The task force on diabetes and cardiovascular diseases of the European Society of Cardiology (ESC) and of the European Association for the Study of Diabetes (EASD). Eur Heart J 28:88-136

9. Cockcroft DW, Gault MH (1976) Prediction of creatinine clearance from serum creatinine. Nephron 1:31-41

10. Gault MH, Longerich LL, Harnett JD, Wesolowski C (1992) Predicting glomerular function from adjusted serum creatinine. Nephron 3:249-256

11. Hunsicker LG, Adler S, Caggiula A, England BK, Greene T, Kusek JW, Rogers NL, Teschan PE (1997) Predictors of the progression of renal disease in the Modification of Diet in Renal Disease Study. Kidney Int 51:1908-1919

12. Levey AS, Stevens LA, Schmid CH, Zhang YL, Castro AF 3rd, Feldman HI, Kusek JW, Eggers P, Van Lente F, Greene T, Coresh J, CKD-EPI (Chronic Kidney Disease Epidemiology Collaboration) (2009) A new equation to estimate glomerular filtration rate. Ann Intern Med 150:604-612

13. Freeman RV, O'Donnell M, Share D, Meengs WL, Kline-Rogers E, Clark VL, DeFranco AC, Eagle KA, McGinnity JG, Patel K, Maxwell-Eward A, Bondie D, Moscucci M (2002) Nephropathy requiring dialysis after percutaneous coronary intervention and the critical role of an adjusted contrast dose. Am J Cardiol 90:1068-1073

14. Laskey WK, Jenkins C, Selzer F, Marroquin OC, Wilensky RL, Glaser R, Cohen HA, Holmes DR Jr (2007) Volume-to-creatinine clearance ratio: a pharmacokinetically based risk factor for pre diction of early creatinine increase after per-cutaneous coronary intervention. J Am Coll Cardiol 50(7):584-590

15. Rudnick MR, Berns JS, Cohen RM, Goldfarb S (1997) Contrast media-associated nephrotoxicity. Semin Nephrol 17:15-26

16. Pflueger A, Larson TS, Nath KA, King BF, Gross JM, Knox FG (2000) Role of adenosine in contrast media-induced acute renal failure in diabetes mellitus. Mayo Clin Proc 75:1275-1283

17. Katzberg RW, Morris TW, Burgener FA, Kamm DE, Fischer HW (1977) Renal renin and hemodynamic responses to selective renal artery catheterization and angiography. Invest Radiol 12:381-388

18. Heyman SN, Brezis M, Reubinoff CA, Greenfeld Z, Lechene C, Epstein FH, Rosen S (1988) Acute renal failure with selective medullary injury in the rat. J Clin Invest 82:401-412 
19. Heyman SN, Brezis M, Epstein FH, Spokes K, Silva P, Rosen S (1991) Early renal medullary hypoxic injury from radiocontrast and indomethacin. Kidney Int 40:632-642

20. Ronco C, Stacul F, McCullough PA (2013) Subclinical acute kidney injury (AKI) due to iodine-based contrast media. Eur Radiol 23(2):319-323
21. Ronco C, Kellum JA, Haase M (2012) Subclinical AKI is still AKI. Crit Care 16(3):313

22. Ribichini F, Graziani M, Gambaro G et al (2010) Early creatinine shifts predict contrast-induced nephropathy and persistent renal damage after angiography. Am J Med 123:755-763 